\title{
Hurtigtester ved halsinfeksjon
}

Selv om hurtigtestene for gruppe A-streptokokker er relativt nøyaktige, bør de ikke brukes ukritisk.

Halsinfeksjon er en hyppig tilstand i allmennpraksis, men det kan være vanskelig å skille mellom bakteriell og viral årsak. Bakterielle årsaker gjelder i hovedsak gruppe Astreptokokker, som kan gi lokale eller invasive komplikasjoner. I Norge anbefales antibiotikabehandling i moderate til alvorlige tilfeller av bakterielle halsinfeksjoner. Hurtigtester for å påvise gruppe A-streptokokker gir et raskere svar enn mikrobiologisk undersøkelse, men hvor pålitelige er disse

testene? I en metaanalyse som nylig er publisert i tidsskriftet Pediatrics er hurtigtestenes diagnostiske nøyaktighet vurdert hos pasienter med bakteriell halsbetennelse bekreftet ved dyrking (1).

Metaanalysen omfatter 48 studier, åtte ulike typer hurtigtester og materiale fra nesten 24000 pasienter. Hurtigtestenes sammenlagte estimat for sensitivitet var 0,86 $(95 \%$ KI $0,83-0,88)$ og for spesifisitet 0,96 $(95 \%$ KI $0,94-0,97)$. Studier som bare

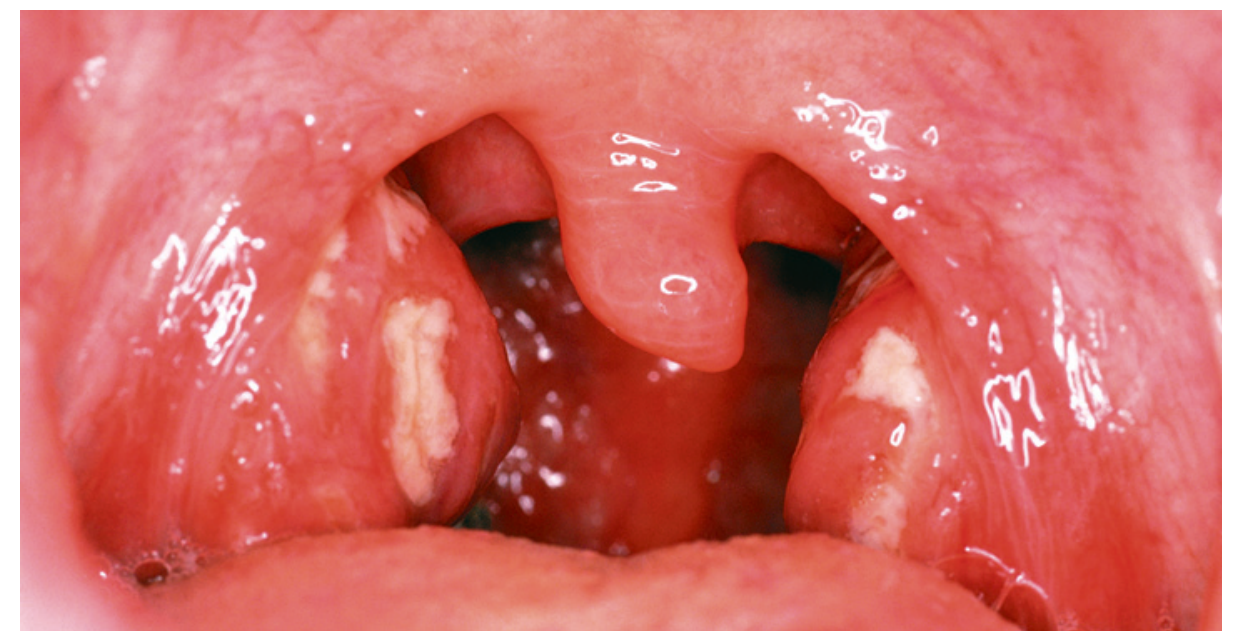

Illustrasjonsfoto: Science Photo Library hadde omfattet barn, ga liknende estimater. Det var store forskjeller mellom de ulike hurtigtestproduktene når det gjaldt sensitivitet, mens spesifisiteten var gjennomgående høy. Gruppen av hurtigtester som var basert på molekylære teknikker, hadde de beste testegenskapene-med en samlet sensitivitet på $0,92(95 \%$ KI $0,89-0,95)$ og en spesifisitet på 0,99 (95\% KI 0,97-0,99).

- Denne grundige gjennomgangen viser at det er nyttig for legen å gjøre seg kjent med sitt eget apparats sensitivitet og spesifisitet, sier Sigurd Høye, som er allmennlege og forsker ved Antibiotikasenteret for primærmedisin, Avdeling for allmennmedisin, Universitetet i Oslo.

- Selv om hurtigtestene for gruppe Astreptokokker er relativt nøyaktige, bør de ikke brukes ukritisk. Både faren for falskt negativt svar, muligheten for bærertilstand av gruppe A-streptokokker og muligheten for at infeksjonen kan skyldes gruppe Celler gruppe G-streptokokker innebærer at legen må gjøre en klinisk vurdering. Kun pasienter med moderate symptomer bør testes hos pasienter med kraftige eller milde symptomer bør de kliniske forhold avgjøre hvorvidt antibiotika skal forskrives, sier Høye.

\section{Lise Mørkved Helsingen}

Tidsskriftet

\section{Litteratur}

1. Lean WL, Arnup S, Danchin M et al. Rapid diagnostic tests for group A streptococcal pharyngitis: a meta-analysis. Pediatrics 2014; 134: 771-81.

\section{Mutasjonen bak Stormorkens syndrom er påvist}

\section{Stormorkens syndrom ble \\ beskrevet første gang i 1985. \\ Nå har amerikanske og norske \\ forskere funnet mutasjonen som \\ forårsaker syndromet.}

I 1985 beskrev professor Helge Stormorken ved Institutt for tromboseforskning på Rikshospitalet to norske pasienter med blødninger, leggkramper, dysleksi og nedsatt mørkesyn som de mest fremtredende plagene. I tillegg manglet pasientene milt. Syndromet fikk betegnelsen Stormorkens syndrom (Online Mendelian Inheritance in Man (OMIM) 185070). Arvegangen er autosomalt dominant. På verdensbasis er det identifisert bare 13 pasienter med dette syndromet, og årsaken har vært ukjent.

I to artikler publisert våren 2014 beskrives funnet av mutasjonen som forårsaker
Stormorkens syndrom: En heterozygot mutasjon i genet som koder for kalsiumsensoren STIM1. Bak studiene står en amerikansk forskergruppe (1) og en gruppe ved Avdeling for medisinsk genetikk ved Universitetet i Oslo og Oslo universitetssykehus (2).

STIM1 sitter i membranen på endoplasmatisk retikulum, interagerer med en kalsiumkanal i plasmamembranen og stimulerer denne når kalsiumnivået $i$ endoplasmatisk retikulum er lavt. I celler fra pasientene med Stormorkens syndrom virker ikke sensoren som den skal. Kalsium blir sluppet inn i cellen hele tiden, uavhengig av dens behov. Denne manglende reguleringen i muskelceller og blodplater gir de sentrale symptomene hos pasientene.

- Bare dertil skolerte fagfolk kan virkelig nyte disse originale funnene. Det er gjort et møysommelig og imponerende arbeid i Eirik Frengens forskningsgruppe, sier Helge Stormorken, professor emeritus og medforfatter av den norske artikkelen.
- En omfattende analyse i samarbeid med det nasjonale senteret for dypsekvensering (NSC) resulterte $\mathrm{i}$ at genfeilen ble identifisert, og eksakt samme mutasjon er nå påvist $i$ alle de 13 kjente pasientene fra ni familier, sier Eirik Frengen, professor og leder av den norske forskergruppen. - STIM1 er nylig vist å være viktig blant annet i utvikling av beinvev. Forhåpentligvis vil videre studier av effekten av den nyoppdagede genfeilen kunne gi ny kunnskap om også andre sykdommer, slik som beinskjørhet, sier Frengen.

\section{Lise Mørkved Helsingen}

Tidsskriftet

\section{Litteratur \\ 1. Nesin V, Wiley G, Kousi M et al. Activating muta- tions in STIM1 and ORAI1 cause overlapping syn- dromes of tubular myopathy and congenital mio- sis. Proc Natl Acad Sci U S A 2014; 111: 4197-202. \\ 2. Misceo D, Holmgren A, Louch WE et al. A domi- nant STIM1 mutation causes Stormorken syn- drome. Hum Mutat 2014; 35: 556-64}

